\title{
Broadcast burning slash favors black spruce reproduction on organic soil in Minnesota
}

\author{
WILLIAM F. JOHNSTON \\ USDA Forest Service \\ North Central Forest Experiment Station \\ Grand Rapids, Minnesota
}

Slash burning tests showed that summer broadcast burning is superior to both winter progressive burning and no disposal for reproducing black spruce on clearcut areas in north-central Minnesota. Broadcast burning is superior because: 1 it exposes moist sphagnum moss and consumes dry mosses, and thus produces favorable seedbeds over the entire clearcut area; 2 it kills all residual conifers and eradicates dwarf mistletoe; and 3 assuming slash disposal is prescribed, it is much cheaper than progressive burning.

Black spruce (Picea mariana (Mill.) B.S.P.), the major pulpwood species on extensive areas of organic soil in north-central Minnesota, is harvested by clearcutting and hence deep accumulations of slash usually cover much of the ground. Previous studies on such clearcut, organic-soil areas in Minnesota and Manitoba show that black spruce often reproduces poorly because favorable seedbeds such as sphagnum moss are covered by slash (Heinselman 1959, Jarvis and Cayford 1961). So, during the past decade the North Central Forest Experiment Station and Minnesota's Division of Lands and Forestry have cooperated in testing two methods of slash burning to better prepare clearcut spruce areas for reproduction.

\section{Procedure}

The two burning methods were broadcast burning of unpiled slash in summer and progressive burning of piled slash in winter. Broadcast burning was done on large patches and wide strips; progressive burning was done on small patches and narrow strips. Control areas (no slash disposal) were similar in size and adjacent to progressively burned areas (Table 1). Natural seeding was relied on in all cases except large patches, where about 100,000 black spruce seeds per acre were broadcast with a hand seeder.

The burning tests were made near Big Falls in north-central Minnesota where flat expanses of organic soil cover the bed of glacial Lake Agassiz. Before cutting, all but three test areas supported nonbrushy, pure stands of black spruce with a moss surface dominated by Sphagnum spp., Calliergonella schreberi (Brid.) Grout, and Dicranum rugosum (Hoffm.) Brid. The other three areas were in a brushy stand of spruce and some tamarack (Larix laricina (Du Roi) K. Koch) with an understory dominated by speckled alder (Alnus rugosa (Du Roi) Spreng.).

Broadcast burning was done 4 to 11 days since 0.1 inch of rain, with ignition beginning about noon.

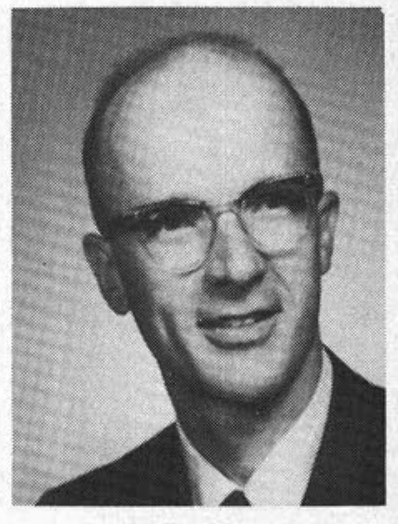

\begin{tabular}{|c|c|c|c|}
\hline \multicolumn{2}{|c|}{ Treatment } & \multirow{2}{*}{$\begin{array}{l}\text { Patch size } \\
\text { or } \\
\text { strip width }\end{array}$} & \multirow{2}{*}{$\begin{array}{c}\text { Numbe } \\
\text { of } \\
\text { areas }^{2}\end{array}$} \\
\hline Burning & Clearcutting & & \\
\hline Broadcast & $\begin{array}{l}\text { Large patch } \\
\text { Wide strip }\end{array}$ & $\begin{array}{l}32-65 \text { acres } \\
31 / 2-5 \text { chains }\end{array}$ & $\begin{array}{l}3 \\
4\end{array}$ \\
\hline Progressive & $\begin{array}{l}\text { Small patch } \\
\text { Narrow strip }\end{array}$ & $\begin{array}{l}1 / 2-1 \text { a } \\
2 \text { chai }\end{array}$ & $\begin{array}{l}3 \\
3\end{array}$ \\
\hline $\begin{array}{l}\text { Control (no slash } \\
\text { disposal) }\end{array}$ & $\begin{array}{l}\text { Small patch } \\
\text { Narrow strip }\end{array}$ & $\begin{array}{l}1 / 4-1 / 2 \text { acre } \\
1 \text { chain }\end{array}$ & $\begin{array}{l}3 \\
3\end{array}$ \\
\hline \multicolumn{4}{|c|}{$\begin{array}{l}{ }^{1} \text { All areas were nonbrushy except one large patch and two } \\
\text { wide strips. } \\
{ }^{2} \text { Each broadcast-burned area consisted of only one patch or } \\
\text { strip; each of the other areas contained an average of four patches } \\
\text { or two strips. }\end{array}$} \\
\hline
\end{tabular}

During burning, minimum relative humidity was 30 to $54 \%$, maximum air temperature $64^{\circ}$ to $94^{\circ} \mathrm{F}$., and maximum wind speed 5 to 15 miles per hour. A line of back fire was started with drip torches on one side of the clearcut area and then successive lines of head fire were ignited upwind until the entire area was burned (Fig. 1). In contrast, progressive burning was done when the ground was frozen

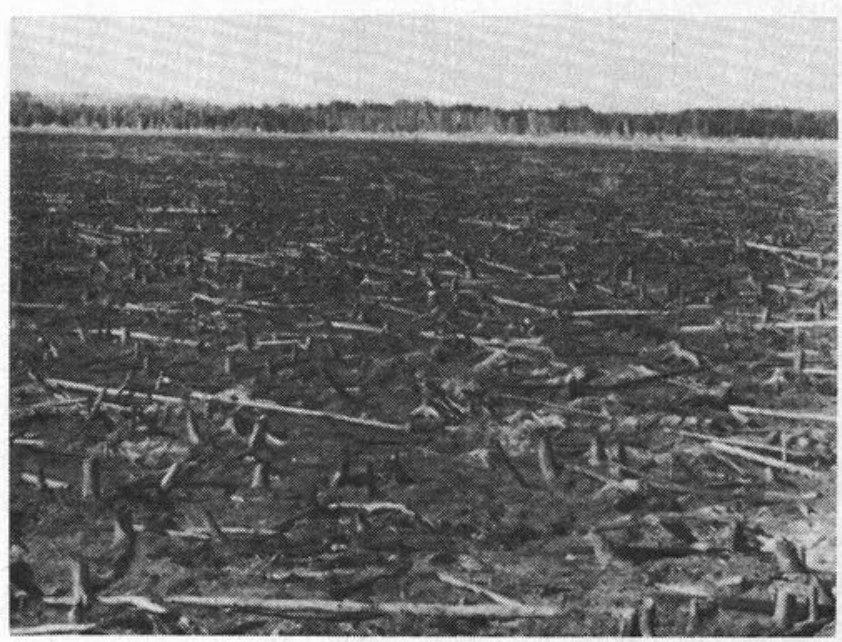

Fig. 1. Large, clearcut patch of black spruce soon after broadcast burning of slash in summer. Only stumps and main stem of tops remain.

February 1971 The Forestry Chronicle 
and covered with snow. Fire was confined to scattered spots 10 to 15 feet in diameter or rows about 8 feet wide (Fig. 2).

Black spruce reproduction was sampled 2 to 6 years after treatment on 80 to 120 milacre plots systematically located throughout each test area. Since the control areas (no slash disposal) were cut and sampled before the burned areas, their reproduction data are from an earlier report (Heinselman 1959).

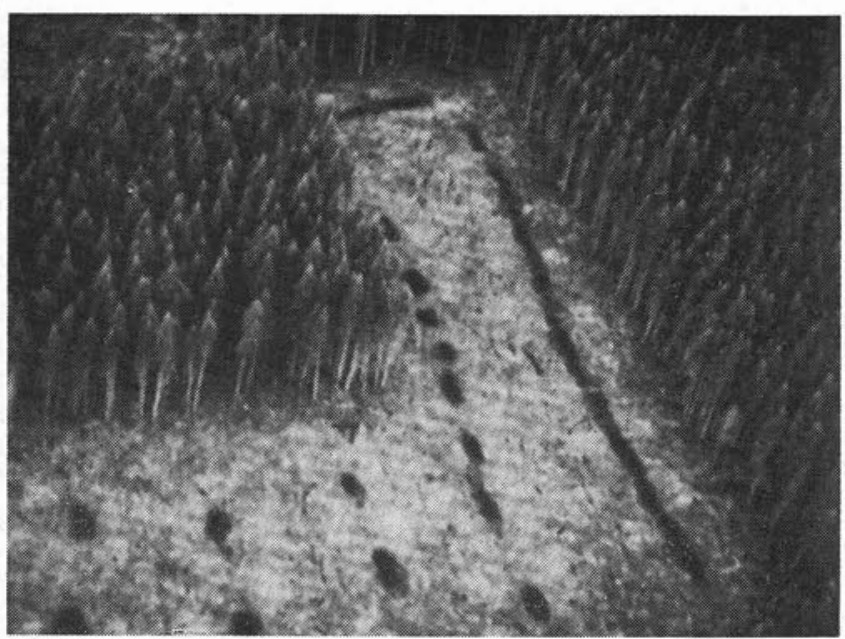

Fig. 2. Small, clearcut patch of black spruce showing scattered, dark areas where slash was burned progressively during winter harvesting.

\section{Results and discussion}

Black spruce reproduction was much denser and better distributed on areas where slash was burned than where it was left (Table 2). Exposing sphagnum moss was the main reason for ample reproduction on progressively burned areas. Although $92 \%$ of the ground remained unburned, sphagnum seedbeds, which covered $47 \%$ of this ground and which usually remain moist after exposure, supported $74 \%$ of the spruce reproduction. Burned spots contained extremely dense reproduction but contributed only $15 \%$ of the spruce reproduction because they covered such a small proportion $(8 \%)$ of the ground.

If sphagnum moss had been sparse, however, black spruce would probably have reproduced poor-

TABLE 2. Black spruce reproduction 2 to 6 years after various methods of slash burning and clearcutting

\begin{tabular}{|c|c|c|c|c|}
\hline \multicolumn{2}{|c|}{ Treatment } & \multirow{2}{*}{$\begin{array}{l}\text { Time } \\
\text { since } \\
\text { treatment }\end{array}$} & \multicolumn{2}{|c|}{ Reproduction } \\
\hline Burning & Glearcutting & & $\begin{array}{c}\text { Stems } \\
\text { per acre } \\
\text { (Number) }\end{array}$ & $\begin{array}{r}\text { Milacre } \\
\text { stocking } \\
\text { (Percent) }\end{array}$ \\
\hline Broadcast & $\begin{array}{l}\text { Large patch } \\
\text { Wide strip }\end{array}$ & $2 \stackrel{2}{-} 4$ & $\begin{array}{r}7,200 \\
12,900\end{array}$ & $\begin{array}{l}80 \\
91\end{array}$ \\
\hline Progressive & $\begin{array}{l}\text { Small patch } \\
\text { Narrow strip }\end{array}$ & $\begin{array}{l}4 \\
4\end{array}$ & $\begin{array}{r}13,900 \\
9,900\end{array}$ & $\begin{array}{l}97 \\
86\end{array}$ \\
\hline $\begin{array}{l}\text { Control (no } \\
\text { slash } \\
\text { disposal) }{ }^{1}\end{array}$ & $\begin{array}{l}\text { Small patch } \\
\text { Narrow strip }\end{array}$ & $\begin{array}{l}4-6 \\
4-6\end{array}$ & 3,700 & 62 \\
\hline
\end{tabular}

ly following progressive burning. This is because the other mosses occurring with sphagnum usually dry out after exposure and thus are poor seedbeds. For example, Calliergonella plus Dicranum covered $33 \%$ of the unburned ground on progressively burned areas but supported only $7 \%$ of the spruce reproduction. It is therefore concluded that progressive burning of slash will result in satisfactory reproduction of black spruce only if sphagnum moss is fairly abundant.

Broadcast burning of slash resulted in ample reproduction of black spruce probably because it not only exposed moist sphagnum moss but also produced favorable seedbeds by consuming dry mosses over the entire clearcut area. Although the relative importance of these two effects was not determined for broadcast-burned areas, burned seedbeds were certainly excellent for reproducing black spruce. For example, moderately burned spots on progressively burned areas had about three times as many spruce seedlings per acre as unburned sphagnum $(32,000$ vs. 10,900$)$. Because the severity of burning was about the same for these burned spots and broadcast burns, it is concluded that broadcast burning of slash will result in satisfactory reproduction of black spruce even if sphagnum moss is sparse.

Besides consuming dry mosses over the entire clearcut area, broadcast burning had other important advantages over progressive burning, which burned only $8 \%$ of the area. First, broadcast burning killed all residual conifers. This freed clearcut areas of old trees and advance growth which usually have little potential except to compete with new seedlings. Second, by killing all black spruce, broadcast burning eradicated dwarf mistletoe (Arceuthobium pusillum Peck) on areas where it occurred. This is important because mistletoe is the most serious pest of spruce ${ }^{1}$. Third, broadcast burning has become much cheaper than progressive burning during the past few years. In 1969, for example, Minnesota's Division of Lands and Forestry broadcast burned seven 40- to 74-acre patches on lowhazard days for an average cost of $\$ 1.73$ per acre. In contrast, progressive burning of hand-piled slash was done by loggers for a stumpage reduction averaging about $\$ 17.00$ per acre. Although this cost could no doubt be reduced by machine piling of slash, broadcast burning would still be cheaper.

Severity of broadcast burning importantly affects the reproduction of both black spruce and competing vegetation on nonbrushy sites. For example, light to moderate broadcast burns averaged 12,700 seedlings per acre, and only $22 \%$ of the stocked plots had seedlings overtopped by competing vegetation (Fig. 3). In contrast, moderately to severely burned seedbeds on progressively burned areas averaged 46,900 spruce seedlings per acre, while unburned sphagnum seedbeds averaged 10,900 seedlings. Similarly, competing vegetation such as

${ }^{1}$ Anderson, Ralph L. The black spruce dwarf mistletoe in
Minnesota. (Unpublished Master's thesis on file at University of Minnesota, St. Paul) 1949. 


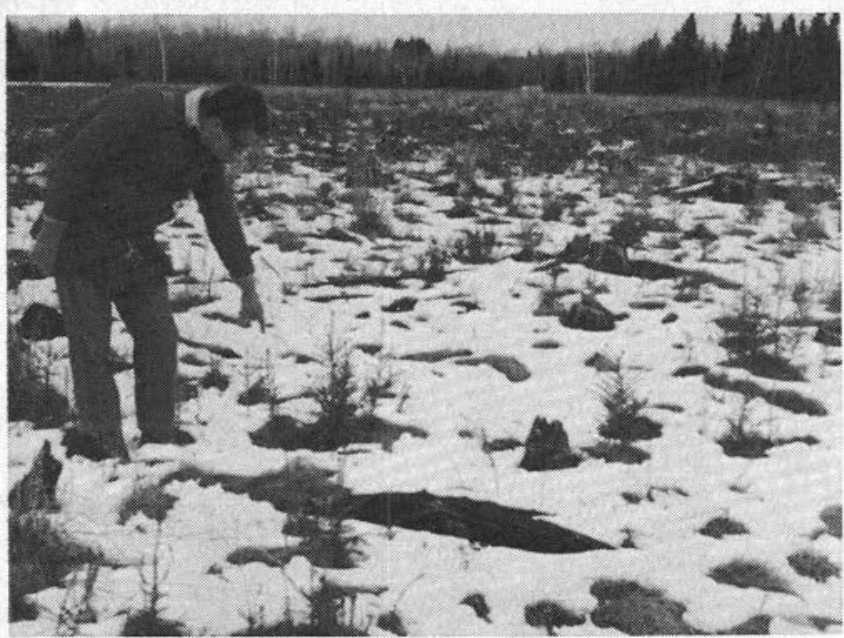

Fig. 3. Black spruce seedlings 5 years after broadcast burning a wide, nonbrushy, clearcut strip. Most of the 15,000 seedlings per acre present after 4 years were free from low-growing sedges (mainly Carex trisperma Dew.) and other vegetation.

willow (Salix spp.), quaking aspen (Populus tremuloides Michx.), and other tree species reproduced densely on these burned seedbeds, whereas surrounding unburned seedbeds had relatively little competing vegetation (Table 3 ). It is therefore concluded that on nonbrushy sites with well distributed sphagnum moss, broadcast burning should be only severe enough to consume slash and kill residual conifers. If sphagnum moss is sparse, however, burning must be severe enough to consume dry mosses over the entire clearcut area in order to produce favorable seedbeds.

TABLE 3. Milacre stocking of various tree seedlings competing with black spruce on progressively burned areas after 4 years

$$
\begin{array}{ccc}
\text { (In percent) } & \text { Burned } \\
\text { seedbeds } & \begin{array}{c}
\text { Unburned } \\
\text { seedbeds }
\end{array}
\end{array}
$$

Quaking aspen

Paper birch

Balsam poplar

Tamarack

Balsam fir

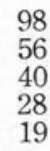

57

14

40

19

120

Basis: number of plots

On brushy sites competing vegetation is an additional problem. For example, on light to moderate broadcast burns an average of $60 \%$ of the stocked plots had spruce seedlings overtopped by other vegetation (Fig. 4). More severe burning might have reduced the growth of this vegetation by killing more of the plants' root systems. Such burning, however, could cause deep ground fires and would increase costs. Hence, a new study is underway on brushy sites to determine how competing vegetation is affected by various burning conditions.

Black spruce reproduces well, of course, only if broadcast-burned areas are amply seeded. Results indicated that natural seeding should be adequate on strips 5 chains wide with a seed source on both sides or 4 chains wide with a seed source only on the windward side. Since direct seeding of 100,000 seeds per acre resulted in ample reproduction on large patches, less seed should be adequate and would cost less. Further, snowmobile seeding,

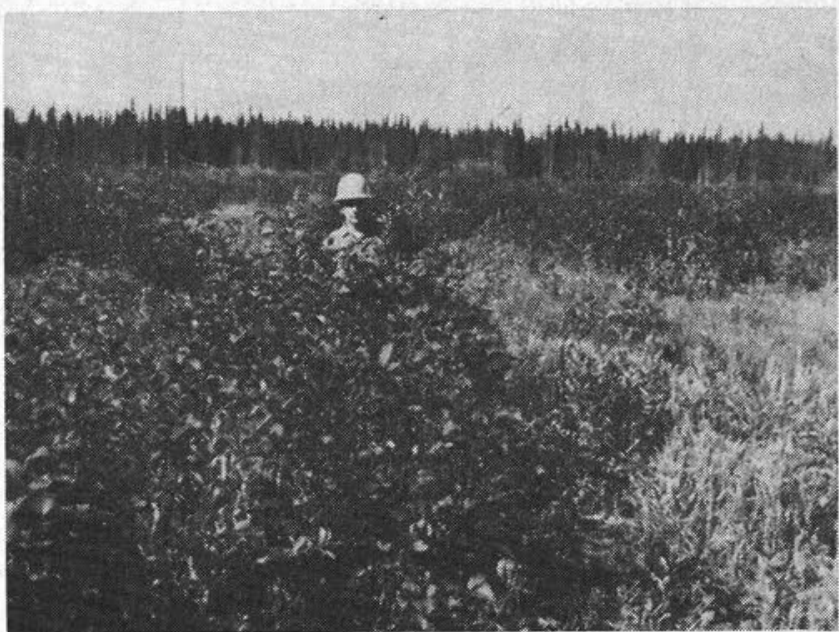

Fig. 4. Speckled alder and grass (mainly Calamagrostis canadensis (Michx.) Beauv.) 3 years after broadcast burning a large, brushy, clearcut patch. Most of the 6,000 black spruce seedlings per acre present after 2 years were overtopped.

which is being tested by Minnesota's Division of Lands and Forestry, should cost much less than hand seeding (Larson and Jamrock 1969). It must still be determined, however, whether large patches can be cut, burned, and seeded cheaper than wide strips can be cut and burned only.

In summary, it is concluded that broadcast burning is superior to both progressive burning and no disposal of slash for reproducing black spruce on clearcut, organic-soil areas. Although this conclusion is based only on tests made in north-central Minnesota, it is probably valid for similar areas throughout the northern Lake States and adjacent Canada. Broadcast burning is superior because: 1/ it exposes moist sphagnum moss and consumes dry mosses, and thus produces favorable seedbeds over the entire clearcut area; 2 / it kills all residual conifers and eradicates dwarf mistletoe; and $3 /$ assuming slash disposal is prescribed, it is much cheaper than progressive burning.

\section{Le brûlage favorise la régénération de l'épinette noire dans les sols organiques du Minnesota}

Des expériences de destructions par le feu des déchets de coupe ont montré que le brûlage d'été des déchets épars est supérieur à la fois au brûlage progressif d'hiver et à l'absence de traitement par le feu pour favoriser la régénération de l'épinette noire dans les coupes rases du centre-nord du Minnesota. Le brûlage des déchets épars est supérieur parce que 1/ en exposant la tourbe humide et en consumant les mousses sèches, il dispose des lits de germination adéquats sur toute la surface rasée; 2 / il tue tous les conifères résiduels et extirpe le gui-nain; 3/ en considérant la destruction des déchets nécessaires, il est moins coûteux que le brûlage progressif.

\section{Literature cited}

HEINSELMAN, M. L. 1959. Natural regeneration of swamp black spruce in Minnesota under various cutting systems USDA Prod. Res. Rep. 32. 22 p.

JARVIS, J. M. and J. H. CAYFORD. 1961. Regeneration following various methods of cutting in black spruce stands in Manitoba. Forest. Chron. 37: 336-337, 339-349.

LARSON, HUBERT and EUGENE JAMROCK. 1969. Snowmobile seeding. Tree Planters' Notes 19(4): 1-3. 